\title{
Accounting
}

\section{The effect of the human resources cycle in improving the effectiveness of the accounting information system} in Jordanian banks

\author{
Ibraheem N. M. Jodeh ${ }^{\text {a* }}$
}

${ }^{a}$ Department of Accounting Sciences, Facuty of Economics and Administrative Sciences, Zarqa University, Zarqa, Jordan

\begin{tabular}{l}
\hline C H R O N I C L E \\
\hline Article history: \\
Received: November 28, 2020 \\
Received in revised format: \\
January 302021 \\
Accepted: March 29, 2021 \\
Available online: \\
March 29, 2021 \\
\hline Keywords: \\
Human Resources Cycle \\
Accounting Information System \\
Jordanian Banks \\
Improving Efficiency
\end{tabular}

\section{A B S T R A C T}

This research aims to study the effect of the human resources cycle in improving the effectiveness of the accounting information system in Jordanian banks by measuring the effect of the number of employees, total training expenditures, the total of salaries and rewarding workers and the total expenditures of workers in Jordanian banks on improving the effectiveness of the accounting information system in Jordanian banks through the net profit after tax deduction for the years from 2010 to 2019 . The results of the study indicate that there is a statistically significant effect at the level of confidence of $5 \%$ for the number of employees, total training expenditures, and total employee expenditures on improving the effectiveness of the information system in Jordanian banks and the absence of a statistically significant relationship to the effect of total salaries and remunerations of workers, as the parameter was -5.934 . The study recommended measuring the effect of the human resources cycle in improving the effectiveness of the information system in Jordanian banks in terms of liquidity and solvency, and in other business sectors.

C 2021 by the authors; licensee Growing Science, Canada

\section{Introduction}

The human element is one of the most important elements in the system in general, and therefore the most important element of the main accounting information systems, and where it selects, designs and applies the various functions of the accounting information system to improve the effectiveness of the accounting information system in providing accurate, appropriate and complete information in a timely manner to help add value to the organization and improve its effectiveness through the completion of its main and supportive activities. The human resource cycle is considered to be one of the main cycles of business in the system of accounting information according to most researchers, for example Romeney and Steinbart (2012) considered that business cycles are five cycles: revenue cycle, expenditures cycle, production cycle, human resource cycle and the financial cycle. Many specialized researchers summarize that the human resources cycle in the process of preparing monthly salaries, and this is imprecise, or as it is said "narrow the wide", Romney and Steinbart (2012) indicated that the human resource cycle includes interactions between organizations and their employees. These interactions are: hire employees, train them, pay their wages, rate them, upgrade them, and refer them to retirement or not to renew their contracts. Therefore, the human resource, his skill, his knowledge and ability to work and adapt to normal and emergency surrounding environmental conditions are among the most important factors that affect the success of the management and accounting information systems of business organizations and the achievement of their goals and improve their effectiveness, continuity and growth in the short and long term. The effect of the human resources cycle can be quantitatively measured through the number of employees, total paid training expenditures, total salaries and bonuses, as well as the total of employees expenditures that include all types and details of wages and incentives, including: salaries, benefits, bonuses and rewards, training expenses, contribution to social security, contribution to the provident fund, end of service compensation, health insurance, and travel and transportation expenses.

* Corresponding author

E-mail address: ijodeh@zu.edu.jo (I. N. M. Jodeh) 
Commercial banks aim to achieve several goals and indicators to improve their effectiveness through accounting information systems. These indicators measure and evaluate their performance at the local, regional and international levels, including and according to the Jordan Banks Association (2019): total credit facilities granted to customers, total customer deposits, and net profit after tax deduction, the rate of return on assets, and the rate of return on equity. The main objective of this study is to measure the effect of the human resources cycle, which will be quantitatively measured through several indicators, namely: the number of bank employees, total paid training expenditures, total salaries and bonuses, and total employee expenditures in improving the effectiveness of accounting information systems in Jordanian banks, which will be measured by the net profit after tax deduction of the operating Jordanian banks for the years from 2010 to 2019.

\section{Literature review}

The goals of the commercial banks are divided into two parts: general goals and functional goals only (Al-Taher \& Al Khalil, 2006). The general objectives are those related to the bank's general policy, such as achieving growth in the size of the bank's profit at rates greater than the competitors in the banking market. As for the functional goals, they are: profitability, liquidity, safety and Growth. Therefore, we see the banks focus on attracting customers to more deposits on the one hand and providing credit facilities on the other hand. Khalaf (2015), Abdullah (2014) and Al-Bayati and Samara (2013) emphasized that commercial banks accept deposits of individual and corporate customers and then use them to provide credit loans with the intention of achieving the largest possible profit. Here we see an emphasis on the bank's functional goals and the need to balance within the limits of acceptable indicators and measures of credit facilities, total customer deposits and profitability ratios, and also by achieving an acceptable degree of safety through the return on equity and the return on assets, as the rate of profit affects all these indicators. Olokoyo (2011) affirmed that banks take into consideration the three principles that guide their operations, which are profitability, liquidity and solvency. Wahdan (2017) Conducted a study on the impact of financial risks on the financial performance of Jordanian commercial banks for the period 2008-2015, the results of the study showed that credit risk and capital adequacy risks are the most influential on financial performance, the study recommended the necessity of monitoring the granting of credit and using especial strategies and controls by banks help in reducing this risk, the suggested strategies include; Good training for employees, studying the elements of granting credit, optimum utilization of bank assets and the necessity of having a reference interest rate in the Jordanian market. The study Jeet \& Aspal (2020) showed that there is a significant positive relationship between the financial performance (profitability) of public sector banks in India and human capital, liquidity, management efficiency and asset quality. Aladwani (2002) studied (An integrated performance model of "information system projects" ) aimed to present and demonstrate an integrated model for the performance of information systems to help in evaluating the performance of these systems and the factors affecting them. It concluded that an information system must have a number of important characteristics in order to function effectively, which are technological characteristics (technology support), system project characteristics (size of the project team), task characteristics (clarity of objectives), operating characteristics (ability to solve problems), personnel characteristics (Employee experience), organizational characteristics (management support). It recommended adopting a more comprehensive view of the performance of information systems.

The Deutsche Bank's Human Resources Report (2018) indicated that human resources work on shaping the future of work, developing the capabilities of employees to achieve goals and transforming human resources programs into digital programs. Al-Arabi et al. (2015) concluded in their research the importance of using accounting information systems in enhancing the role of human resources management, especially in the recruitment function, the training function, the performance evaluation function and the compensation function. Their study also confirmed how the human resources cycle can use accounting information systems to enhance their functions, which will benefit companies' performance, and they found that the accounting information system is positively linked to enhancing the human resource management cycle. The results of their research Grande et al. (2011) on the impact of accounting information systems on performance evaluation in small and medium companies showed that there is a positive relationship between the use of accounting information systems in financial management and banking and improving performance evaluation, also Harrash et al. (2014) concluded in their research on the positive role of accounting information systems in small and medium enterprises in terms of reliability, suitability and timeliness. Many specialists and researchers in human resources have emphasized the importance of the human element for the success of any institution, provided that the right person is chosen for the appropriate job, and to achieve this, there must be: the employee's familiarity with the nature and tasks of his job scientifically and practically on the one hand and honesty in performing his work on the other hand (Nar, 2020). This is consistent with the basic tasks of human resources from defining the job description of the job and the employee, and hiring accordingly, training, evaluation, salaries, incentives and rewards based on experiences, achievements and evaluation. This is consistent with the results of the study (Al-Shurafa \& Abdel Aal, 2018), methods of developing human resource management in Islamic banks in the Gaza governorates and their impact on achieving ultimate quality, where the results of their study showed the existence of a statistically significant impact of human resource development methods on the overall quality according to the following order: training and development of employees, human resource planning, selection and appointment system and performance evaluation. This is in agreement with the findings of (Al-Hayajneh et al., 2012) that there is a relationship and influence for human resources information systems in identifying training needs, setting goals, implementing, evaluating and following up the effectiveness of training programs. Jawad (2015) study aimed at 
identifying the role of human resource formation in the development and success of the economic enterprise. He found a statistically significant relationship between formation and performance and the existence of a statistically significant effect between motivation and worker performance, and where the study recommended increasing formation programs in proportion to the size of available labor, which raise the institution's efficiency, improve performance, increase its productivity and achieve its goals. Also, Al-Ali (2016) study aimed to demonstrate the impact of human resources information systems on administrative decision-making in commercial banks operating in the Tabuk region, and whereas, the study found an impact of human resources information systems in its dimensions in making administrative decisions in its dimensions in commercial banks,, and where the study recommended focusing on training courses for workers and where they be periodic to increase the efficiency of workers in dealing with technical developments and dedicate such training courses to decision-making. This is consistent with what is meant by the effectiveness of accounting information systems and ways to improve them in business organizations through the ability to achieve goals, the most important of which is to provide appropriate and reliable information that helps decisionmakers from inside and outside the establishment to achieve their goals. Effectiveness means the extent of success in achieving goals, and this means that the degree of effectiveness is measured by the extent of achieving the goals set for it or that were originally found to be achieved. The system that achieves its goals is effective and the system that does not achieve its goals is ineffective (Fadel, 2007: 5). Accordingly, the benefits provided by accounting information systems to improve the effectiveness of operations and activities are evident in helping them achieve the desired goals of commercial banks in survival, growth and profitability (Sturat, 2001: 301).

\section{Research method}

The importance of this study lies in determining the effect of the human resources cycle in improving the effectiveness of the accounting information system in Jordanian banks. It applies to Jordanian banks operating from 2010 to 2019 . This study aims to determine the effect of the human resources cycle in improving the effectiveness of the accounting information system in Jordanian banks to achieve the following goals:

1-Determining the effect of the number of employees on improving the effectiveness of the accounting information system in Jordanian banks.

2-Determining the effect of total training expenditures on improving the effectiveness of the accounting information system in Jordanian banks.

3-Determining the effect of total salaries and bonuses in improving the effectiveness of the accounting information system in Jordanian banks.

4-Determining the effect of the total expenditures of employees on improving the effectiveness of the accounting information system in Jordanian banks.

The problem of the study is to identify and know the effect of the human resources cycle in improving the effectiveness of accounting information systems in Jordanian banks by focusing on the index of net profits after tax deduction for the study years from 2010 to 2019 . This study will answer the following questions:

-What is the role of the number of employees in improving the effectiveness of the accounting information system in Jordanian banks?

-What is the role of total training expenditures in improving the effectiveness of the accounting information system in Jordanian banks?

-What is the role of total salaries and bonuses in improving the effectiveness of the accounting information system in Jordanian banks?

-What is the role of total employee expenditures in improving the effectiveness of the accounting information system in Jordanian banks?

\subsection{Study hypotheses}

$\mathrm{H}_{01}$ : There is no statistically significant effect of the number of employees in improving the effectiveness of the accounting information system in Jordanian banks.

$\mathrm{H}_{02}$ : There is no statistically significant effect of the total training expenditures in improving the effectiveness of the accounting information system in Jordanian banks.

$\mathrm{H}_{03}$ : There is no statistically significant effect of total salaries and bonuses in improving the effectiveness of the accounting information system in Jordanian banks.

$\mathrm{H}_{04}$ : There is no statistically significant effect of the total employee expenditures on improving the effectiveness of the accounting information system in Jordanian banks. 
Study variables:

The study consists of five variables, namely:

1-The number of employees in Jordanian banks

2-Total training expenses for workers in Jordanian banks

3-Total salaries and bonuses for workers in Jordanian banks

4-Total expenses of workers in Jordanian banks

5-Net profit after tax for Jordanian banks

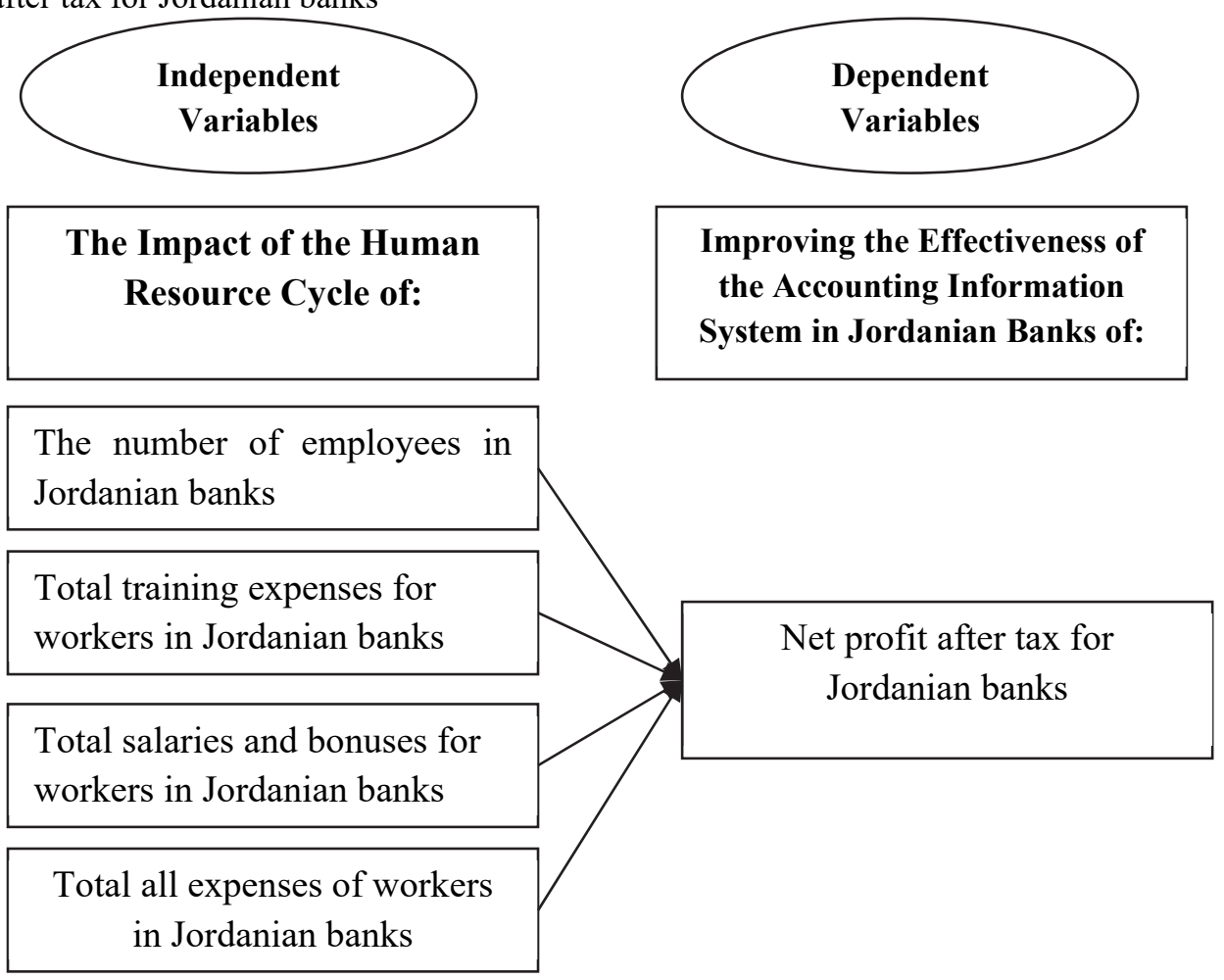

Fig. 1. The proposed method

\section{Research methodology}

The quantitative financial data published in the annual reports of Jordanian banks that are published on their website and published on the Amman Financial Market website and also published in daily newspapers were relied upon in implementation of the Jordanian Companies Law No (22) for year 1997 of article 141 and the Jordanian Banks Law No (28) for year 2000 of article 60. Quantitative financial data give digital information that statistical tests can be applied to, as the data and digital information were relied on in the published annual Jordanian banks' reports only, qualitative data related to behavior, opinions, patterns and other types of information were not adopted because most of the previous studies focused on them through questionnaires, personal interviews and notes and through omitting or not giving quantitative data the big role in explaining the impact of human resources in improving the effectiveness of the accounting information system in banks. In this study, the methods used to analyze quantitative data for Jordanian banks include three steps:

\subsection{Sample identification and selection}

The study focuses on the effect of the human resources cycle in improving the effectiveness of the accounting information system in Jordanian banks, and accordingly the focus was on the element of workers in banks and through the number of employees in operating Jordanian banks, according to Amman Financial Market and the Jordanian Association of Banks, the number of operating Jordanian banks is 24 , and they are as follows: Number of commercial banks were 13 , and 4 for Islamic banks, and 7 for foreign banks which It has branches operating in Jordan.

Through the annual financial reports published for the Jordanian banks, the average number of employees for the last five years from 2015 to 2019 was calculated, the eight banks that achieved the highest average number of employees were selected as a sample for the study as shown in Table 1 below; 
Table 1

The ranking of banks operating in Jordan within the study sample according to the average number of employees for the years 2015-2019

\begin{tabular}{|c|c|c|c|c|c|c|c|}
\hline No & Bank & 2015 & 2016 & 2017 & 2018 & 2019 & average number of employees \\
\hline 1 & Arab Bane & 2934 & 2990 & 3075 & 3133 & 3236 & 3,074 \\
\hline 3 & Housing Bank for Trade and Finance & 2363 & 2393 & 2,426 & 2,463 & 2,358 & 2,401 \\
\hline 2 & Jordan Islamic Bank & 2148 & 2236 & 2,335 & 2,405 & 2,440 & 2,313 \\
\hline 5 & Cairo Amman Bank & 1,614 & 1,553 & 1,612 & 1,564 & 1,535 & 1,576 \\
\hline 4 & Jordan Bank & 1,489 & 1,578 & 1,675 & 1,583 & 1,547 & 1,574 \\
\hline 7 & Jordan Ahli Bank & 1,416 & 1,379 & 1,206 & 1,216 & 1,186 & 1,281 \\
\hline 6 & Jordan Kuwait Bank & 1,100 & 1,151 & 1,192 & 1,201 & 1,239 & 1,177 \\
\hline 8 & Union Bank & 915 & 1,022 & 1,136 & 1,146 & 1,142 & 1,072 \\
\hline
\end{tabular}

\subsection{Data collection}

Initial quantitative data were collected from the published annual financial reports for Jordanian banks for the years 2010-2019 from the reality of the financial statements (Balance Sheet, Income statement, change in Owner Equity, cash flows) and the disclosures and explanations included in the financial reports according to the applicable regulations and instructions that govern the work of banks Inside Jordan. Where the primary data that represent and express the dependent and independent variables according to the study for the period 2010-2019 were collected. The quantitative preliminary data collected represents the independent variables related to human resources that were quantitatively expressed in this study through: number of employees, training expenditures, salaries and bonuses, total employees' expenditures. As for the initial quantitative data collected, it represents the dependent variable related to improving the effectiveness of accounting information systems in Jordanian banks, which was quantitatively expressed in this study through: Net profit after tax.

\subsection{Data analysis}

To verify a significant statistical relationship that has a significant effect on the human resources cycle in improving the effectiveness of the accounting system in Jordanian banks. All the quantitative data for each independent variable in the study and which were 4, and its effect on the dependent variable in the study were analyzed by using the Multiple Linear Regression analysis and, the t-test at a level of 5\% confidence and also the value of $\mathrm{R}$-squared in explaining the effect of all independent variables on the dependent variable. This analysis represents an appropriate explanation for administrators and researchers (Studenmund, 2016), and where it is a statistically significant effect of the dependent variable being affected by the independent variable if the parameter sign is positive and has a significant value at a 5\% confidence level and the $t$ value is greater than 2 .

\subsection{Analysis and results}

As shown in Table 2 below, the effect of the four independent variables on the dependent variable net profit after tax, hence we can see that there is an effect and a significant relationship between three of the independent variables: the number of employees, training expenses, total employee expenditures and the dependent variable net profit after tax. There is no effect of the independent variable, total salaries and bonuses on the dependent variable net profit after tax and the value of R-squared is 0.7956, meaning that the effect of the four independent factors combined on the dependent variable net profit after tax explains more than $79 \%$ of the change in the dependent variable under study, which is the net profit after tax, this rate is high and reliable. The form of the equation is as follows;

$\mathrm{CF}=8.896+1.632 \mathrm{EMP} .+0.342 \mathrm{TRA} .-5.934 \mathrm{SAL}+5.404 \mathrm{TOT}$.

\section{Table 2}

The effect of the four independent variables on the dependent variable net profit after tax

\begin{tabular}{lllll}
\hline Independent variable & Coefficient & Std. Error & t-Statistic & Prob. \\
\hline constant parameter & 8.896 & 2.541 & 3.501 & 0.001 \\
Number of employees & 1.632 & 0.299 & 5.463 & 0.000 \\
Training expenses & 0.342 & 0.159 & 2.153 & 0.038 \\
Salaries and bonuses & -5.934 & 2.344 & -2.531 & 0.016 \\
Total expenses & 5.404 & 2.285 & 2.365 & 0.024 \\
\hline
\end{tabular}

R-squared

0.796

\subsection{Testing the hypotheses}

$\mathrm{H}_{01}$ : There is no statistically significant effect of the number of employees in improving the effectiveness of the accounting information system in Jordanian banks.

We note from Table 3 below that the first independent variable the number of employees in Jordanian banks has a strong relationship and a statistically significant influence on the dependent variable Net profit after tax of the Jordanian banks is under 
study at a confidence level of 5\% knowing that the value of t-test is at the rate of 5.463 and the significant value is 0.000 , and the value of the parameter is positive 1.632

Table 3

The effect of the first independent variable: the number of employees in Jordanian banks on the dependent variable net profit after tax

\begin{tabular}{lllll} 
Independent variable & Coefficient & Std. Error & t-Statistic & Prob. \\
\hline Number of employees & 1.632 & 0.299 & 5.463 & 0.000
\end{tabular}

Therefore, the null hypothesis is rejected and the alternative hypothesis is accepted, and which is: There is a statistically significant effect of the number of workers in improving the effectiveness of the accounting information system in Jordanian banks.

$\mathrm{H}_{02}$ : There is no statistically significant effect of the total training expenditures in improving the effectiveness of the accounting information system in Jordanian banks.

We note from Table 4 below that the second independent variable, the total expenses of training for workers has a strong relationship and a statistically significant impact on the dependent variable under study the net profit after tax for Jordanian banks is at a confidence level of 5\%, noting that the value of t-test is 2,153 and the significant value is 0.038 , and the parameter value is positive 0.342 .

\section{Table 4}

The effect of the second independent variable: Total training expenditures for workers in Jordanian banks on the dependent variable net profit after tax

\begin{tabular}{cllll}
\hline Independent variable & Coefficient & Std. Error & t-Statistic & Prob. \\
\hline Training expenses & 0.342 & 0.159 & 2.153 & 0.038 \\
\hline
\end{tabular}

Accordingly, the null hypothesis is rejected and the alternative hypothesis is accepted, and which is: There is a statistically significant effect of training expenditures on workers in improving the effectiveness of the accounting information system in Jordanian banks.

$\mathrm{H}_{03}$ : There is no statistically significant effect of total salaries and bonuses in improving the effectiveness of the accounting information system in Jordanian banks.

We note from Table 5 below that the third independent variable, the total salaries and bonuses for workers in Jordanian banks, has no effect on the dependent variable, the net profit after tax for Jordanian banks within the study sample, where the coefficient is negative and is $\mathbf{- 5 . 9 3 4}$ and whereas, the existence of a statistically significant relationship requires that the parameter sign be positive and the t-value is greater than 2 at a 5\% confidence level, as indicated above (Studenmund, 2016).

\section{Table 5}

The effect of the third independent variable: Total salaries and bonuses for workers in Jordanian banks on the dependent variable Net profit after tax

\begin{tabular}{cllll}
\hline Independent variable & Coefficient & Std. Error & t-Statistic & Prob. \\
\hline Salaries and bonuses & -5.934 & 2.344 & -2.531 & 0.016 \\
\hline
\end{tabular}

Therefore, the null hypothesis is accepted: There is no statistically significant effect of total salaries and bonuses for workers in improving the effectiveness of the accounting information system in Jordanian banks.

$\mathrm{H}_{04}$ : There is no statistically significant impact of the total employee expenditures on improving the effectiveness of the accounting information system in Jordanian banks.

\section{Table 6}

The effect of the fourth independent variable: Total expenditures of employees in Jordanian banks on the dependent variable, net profit after tax

\begin{tabular}{cllll}
\hline Independent variable & Coefficient & Std. Error & t-Statistic & Prob. \\
\hline Total expenses & 5.404 & 2.285 & 2.365 & 0.024 \\
\hline
\end{tabular}

We note from Table 6 below that the fourth independent variable, total employee expenditures, had a strong relationship and a statistically significant impact on the dependent variable under study, net profit after tax for Jordanian banks is at a confidence 
level of 5\% knowing that the t-test value is at 2.365 and the significant value is 0.024 , and the parameter value is positive 5.404. Therefore, the null hypothesis is rejected and the alternative hypothesis is accepted, which is: There is a statistically significant effect of the total expenditures of workers in improving the effectiveness of the accounting information system in Jordanian banks.

\section{Conclusions}

The results of the study are limited to analyzing the data and testing the study hypotheses as follows;

1- The presence of a statistically significant effect (the first hypothesis) the effect of the number of employees on improving the effectiveness of the accounting information system in Jordanian banks through a strong relationship and a significant impact with statistical significance on the dependent variable Net profit after tax of the Jordanian banks under study at a confidence level of $5 \%$. The value of t-test is 5.463 , the significant value is 0.000 , and the parameter value is positive 1.632 .

2- Rejecting the first null hypothesis and accepting the alternative hypothesis, which is: There is a statistically significant effect of the number of workers in improving the effectiveness of the accounting information system in Jordanian banks.

3- The presence of a statistically significant impact (the second hypothesis) total training expenditures of employees to improve the effectiveness of the accounting information system in Jordanian banks through a strong relationship and a statistically significant impact on the dependent variable under study Net profit after tax of Jordanian banks at a confidence level 5 Note that the value of t-test is 2.153 and the significant value is 0.038 , and the parameter value is positive 0.342 .

4- Rejecting the second null hypothesis and accepting the alternative hypothesis, which is: There is a statistically significant effect of training expenditures of workers in improving the effectiveness of the accounting information system in Jordanian banks.

5- The lack of a statistically significant effect (the third hypothesis) total salaries and bonuses for workers to improve the effectiveness of the accounting information system in Jordanian banks through the significant impact of statistical significance on the dependent variable under study Net profit after tax of Jordanian banks within the study sample where the fixed parameter was coefficient has a negative sign with a rate of -5.934 , whereas for the existence of a statistically significant relationship it is required that the sign of the coefficient be positive and the value of $t$ is greater than 2 at a $5 \%$ confidence level.

6- Accepting the third null hypothesis, which is there is no statistically significant effect of the total salaries and bonuses for workers in improving the effectiveness of the accounting information system in Jordanian banks.

7- The presence of a statistically significant effect (the fourth hypothesis) total employees expenditures on improving the effectiveness of the accounting information system in Jordanian banks through a strong relationship and a statistically significant impact on the dependent variable net profit under study after tax for Jordanian banks at a confidence level of 5\% noting that the value of t-test is at the rate of 2.365 and the significant value is at 0.024 , and that the value of the parameter is positive 5.404.

8- Rejecting the fourth null hypothesis and accepting the alternative hypothesis, which is: There is a statistically significant effect of the total expenditures of workers in improving the effectiveness of the accounting information system in Jordanian banks.

9- The presence of an effect of the four independent factors combined on the dependent variable net profit after tax, explains more than $79 \%$ of the change in the dependent variable under study, which is net profit after tax, as the value of R-squared is 0.7956, which means that the independent variables explain greatly the change in improving the effectiveness of the accounting information system for Jordanian banks through the change in net profit after tax.

10- The effect of the human resources cycle on improving the effectiveness of the accounting information system in Jordanian banks is through the number of employees, the total of training expenditures, the total expenditures of employees, and the absence of a statistically significant relationship to the total salaries and bonuses.

\section{Recommendations}

The researcher recommends the following;

1- There is an impact of the human resources cycle in improving the effectiveness of the accounting information system in Jordanian banks through the number of employees, total training expenditures and total expenditures of workers through the effect on net profit after tax. We recommend that the impact be studied in terms of liquidity and financial solvency.

2- There is no effect of the human resources cycle in improving the effectiveness of the accounting information system in Jordanian banks through the total salaries and bonuses employed through the effect on the net profit after tax. We recommend studying the effect in terms of liquidity and financial solvency. 
3- The researcher recommends studying the effect of other business cycles (revenue cycle, expenditures cycle, production cycle and financial cycle) on improving the effectiveness of the accounting information system in Jordanian banks in terms of profitability, liquidity and solvency.

4- The researcher recommends studying the effect of the human resources cycle in improving the effectiveness of the accounting information system in other business sectors, such as financial, industrial, commercial, service and non-profit sectors.

\section{References}

Abdullah, K. A. (2014). Banking Operations and Modern Accounting Methods. Wael Publishing \& Distribution House, $7^{\text {th }}$ ed., Amman - Jordan.

Aladwani, A. M. (2002). An Integrated Performance Model of Information Systems Projects. Journal of Management Information Systems, 19(1), 187-212

Al- Ali, F B. M. (2016). Human resources information systems and their impact on administrative decision-making: a field study on commercial banks in the Tabuk region. Journal of the Faculty of Commerce for Scientific Research - Alexandria University, 53(1).

Al-Bayati, T. F., \& Samara, M. R. (2013). Money, Banks and Contemporary Economic Variables. Wael Publishing and Distribution, $1^{\text {st }}$ ed. Amman- Jordan.

Al-Arabi, A. M., Abu Taber, T. A., Alaryan, L. A., \& Abu Haija, A. A. (2015). The Role of Accounting Information Systems in Enhancing Human Resources Management Cycle in Jordanian Islamic Banks an Empirical Study. Australian Journal of Basic and Applied Sciences, 9(20), 437-441.

Al-Shurafa, Y.A.T., \& Abdel Aal, H. R. A. (2018). Methods of Developing Human Resource Management in Islamic Banks in Gaza Governorates and their Impact on Achieving Total Quality. Global Journal of Economics and Business, 5(1), 44-61.

Al-Taher, A., \& Al-Khalil, M. (2006). Money, banks and intermediary institutions. Yazid Publishing House, $1^{\text {st }}$ ed. Amman - Jordan.

Association of Banks in Jordan. (2019). Booklet No. 3, Volume No. 10. Comparative Performance of Banks Operating in Jordan during 2017-2018. Booklet No. 3. Volume No. 10. Amman - Jordan.

Deutsche Bank. Germany. Human Resources Report (2018). https://www.db.com/ir/en/download/Deutsche_Bank_Human_Resources_Report_2018.pdf

Fadel, A. K. M. (2007). The extent of the influence of environmental, organizational and behavioral factors and technology on the effectiveness of accounting information systems for commercial banks in the Republic of Yemen. Unpublished Master thesis. Al al-Bayt University, Jordan.

Grande, E.U., Estébanez, R. P., \& Colomina, C. M. (2011). The Impact of Accounting Information Systems (AIS) on Performance Measures: Empirical Evidence in Spanish. The International Journal of Digital Accounting Research, 11, 25-43.

Harash, E., Al-Timimi, S., \& Radhi, A. H. (2014). Influence of Accounting Information Systems (AIS) on Performance of Small and Medium Enterprises (SMEs) in Iraq. Journal of Business \& Management, 3(4),48-57.

Hayajneh, O. M. R., Al-Omari, B. A., Al-Mobaideen, H. O., \& Allahawiah, S. R. (2012). The Impact of Human Resources Information Systems in Improving the Training Process in Industrial Firms. European Scientific Journal, 8(25).

Jawad, O. (2015). The Role of Human Resources Training in the Development and Success of the Economic Enterprise. Master Thesis. Abi Bakr Belkaid University. Algeria.

Jeet, v., \& Aspal, P. k. (2020). The Determinant of Financial Performance of Indian Public Sector Banks- A Panel Data Approach. International Journal of Financial Research, 11(5), 285-295.

Khilaf, D. (2015). Commercial Banks and their Role in Financing Foreign Trade. Master Thesis. Umm El-Bouaghi University. Algeria.

Nar, M. (2020). The Relationship Between Human Capital and Financial Development: A Case Study of Turkey. International Journal of Financial Research, 11(1), 157-170.

Olokoyo, F. O. (2011). Determinants of Commercial Banks' Lending Behavior in Nigeria. International Journal of Financial Research, 2(2), 61-72.

Romney, M. B., \& Steinbart, P. J. (2016). Accounting Information Systems. (Ed.14). London: Pearson.

Studenmund, A. H. (2016). $\beta$ Using Econometrics a Practical Guide. (Ed.7). London: Pearson.

Sturat, B. (2001). Knowledge Management Systems: theory and practice. (Ed.1). Engage Learning Business Press.

The Ministry of Finance. Amman - Jordan. The Jordanian Banks Law No (28) for year 2000.

The Ministry of Industry, Trade and Supply. Amman - Jordan. The Jordanian Companies Law No (22) for year 1997.

Wahdan, T. F. M. (2017). The Effect of Financial Risks on the Financial Performance of Cmmercial Banks (An Empirical Study on Commercial Banks Listed in Amman Stock Exchange). Master Thesis. Zarqa University. Zarqa - Jordan.

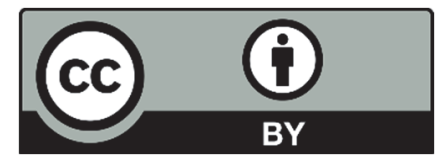

(C) 2021 by the authors; licensee Growing Science, Canada. This is an open access article distributed under the terms and conditions of the Creative Commons Attribution (CC-BY) license (http://creativecommons.org/licenses/by/4.0/). 